\title{
A Critical Study of Great Expectations as a Prism to Victorian England
}

\author{
Author: Dr. Prabhat Chourasia \\ Department of English \\ Amity University Jharkhand
}

\begin{abstract}
:
Great Expectations is an eternal masterpiece of Charles Dickens. He shows how circumstances compel us to mold our expectations in various hues. $\mathrm{He}$ is an ace delineator of character and Great Expectations is no exception. It reflects Victorian England in its truest sense. Pip, Joe, Estella, Miss Havisham, Jaggers, Wemmick, Mrs. Joe, and all other characters present the truth and reality of the contemporary time. Pip, the protagonist of this novel is overwhelmed by various expectations. He wants to become rich, notable and one of the most important personalities of England. For this research paper, both the primary and the secondary sources of information are analyzed and used. Let's see how various characters of this novel represent contemporary Victorian Society? The main focus of this article is to bring into consideration the process of maturation and self-discovery, from childhood to adulthood is simply be shown through the character of Pip. Charles Dickens once said, "I love my novels because they are the means to express my experience in contemporary society and the action of its people.
\end{abstract}

\section{Keywords:}

Victorian society, self-discovery, expectations, personality, contemporary

The Victorian Age was a period of dramatic change that brought England to its highest point of development as a world power. It was the age of invention, industrial advancement, the passage of the Reform Bill, the advancement of science and technology, and many more. Society was divided into two broader ways: Capitalists and laborers; stability and social unrest. It was a period of unprecedented material progress, imperial expansion, political and constitutional development. Where there is material progress there is social unrest as in such an economy, rich becomes richer and poor becomes poorer. The poorer are dissatisfied and they look forward to changing their lot either by following good ways by following the bad ways.

False seriousness, hypocrisy, self-righteousness, mannerism, etc. were in practice by the rich/elite class. The character of Miss Havisham is just like that of a hypocrite. She is too mysterious to be understood. The opening chapter of Great Expectations depicts the appearance and disappearance of the two convicts which proves the fact that though progress and prosperity were prevalent in the society yet it was not free from crime and criminals. It is also shown through the character of Magwitch that people like him is not a hypocrite but he does what he is and helps others too. It is Magwitch who helps Pip with money and not Miss Havisham. Everyone thinks that it was Miss Havisham who helped him but she did never do that nor did she tell anyone the truth.

The relationship between Pip and his sister Mrs. Joe is quite sour like that of tamarind but Joe and Pip are like friends. Joe protects him from the wrath of Mrs. Joe. He is like a father figure for Pip. Pip works with him in 
the forge as an apprentice but Joe never treats him rudely and he does always have a soft corner for Pip. When Pip is invited to Satis house to play with Estella, Pip starts looking forward to changing his life. He wanted to become a gentleman instead of being a blacksmith. Estella treats him cruelly but he bears all these things as he hopes that Miss Havisham may help him to change his lot.

The hollowness of the high class can simply be seen in the character of Miss Havisham as she has kept the banquet table of her marriage day as it was and she keeps on wearing her wedding gown. She teaches Estella to break the heart of men as her heart is broken by a man who ditched her on her wedding day. It was a plan/trick played by her as an act of revenge on everyman. She uses Estella as a tool to take revenge. Pip was invited to the Satis house to play with Estella so that they may develop friendship and love then she breaks his heart. Pip takes all the wounds as a token of love from Estella but he is aware of his low social standing and wants to change his life and live like that of a gentleman. He wants to live in London with all the luxury. His wish comes alive when an unknown benefactor gives him a lot of money. He thinks that Miss Havisham would have helped him but it was someone else. The mystery unfolds towards the end of this novel.

As soon as Pip receives the money he leaves for London. He falls prey to many bad habits like playing cards, winning, and spend thrifty. A gentleman knows and manages wealth and people both; one who follows mannerism in his life and one who knows that money is a part of life it is not the heart of life. That one must not give all the importance to money. The human relationship cannot be bought with money. But the irony with Joe's character is that though he is rich he doesn't know how to maintain a personal relationship. He cares a fig about the people around and he insults them like anything. He does always forget his root which is the cause of his dissatisfaction and gloom in his life. When Joe visits him in London, he doesn't receive him warmly instead he feels it insulting to call a blacksmith his friend. At this point, it is noteworthy that Joe was the person who never left his sides when no one was there for Pip. But is it the way to repay one's goodness? Pip feels the void that he has created and Joe feels heartbroken at this attitude of Pip.

Pip wants to be a gentleman but he is surrounded by people of a criminal background. His life is bleak and so are the lives of the people around him. His benefactor is a criminal, the father of Estella is a murderer and Miss Havisham herself is too mysterious. He wants to be in the company of the rich and white collared people but he cannot. It's his nemesis that from the beginning till the end his life is full of tragedy and ups and downs. Though his life takes a positive turn towards the end when he visits the Satishouse and sees Estell alone. They fall in love with each other and he also rejuvenates his relationship with Joe and Biddy.

We find the seven colors of a rainbow in this novel which is like a prism to the Victorian Age. At the beginning of this Age, it seemed as if there is a utopia in England but gradually the colonialism and imperialism left an indelible imprint in the mind and hearts of people and they became tyrants, false, hypocrite, and malignant. The false seriousness in the character of its people was at its peak.

Britain was a model of industrial success, individual freedom, and constitutional government under the reign of Queen Victoria but Englishmen had been suffering also. The lower middle class and the laborers were the worst sufferers. They found it very difficult to maintain their family with a meagre income. The immense population growth resulted in unemployment and poverty. For example, the lives of Pip and Joe.

Upper and industrial middle-classes believed in a policy of "laissez-faire" ie. non-interference with industry or with the national economy to promote free trade and free competition. It benefited the capitalist and the industrialist but the working class was the worst sufferers. Life for them was to keep their body and soul together. They used to work day and night but their income was too low to meet the ends.

The people of the upper class were full of dissatisfaction and hypocrisy. They found solace nowhere. The condition of the poorer was the worst. They faced appalling living conditions, a high death rate, and illiteracy. 
They were like the withered rootless weeds. The children of this class faced exploitation, hunger, and a perplexed state of mind. Their childhood had been wasted on streets and warehouses. Child labor was a very common phenomenon those days. Children below the age of 14 were put in hazardous works. Many novels of Charles Dickens depict the same problem of the Victorian society like Oliver Twist, Bleak House, etc.

The novel of Charles Dickens is a prism to Victorian England in many ways. First, it encompasses all the features of English Society and the people living and behaving in it. The society was divided in upper and lower strata. The mental setup of the people was vividly shown by Charles Dickens in his novel especially in Great Expectations. He shows the two waves of Victorianism in almost all his novels. He depicted the lives of common people so vividly that we feel as if we are watching them and their actions. Literature is the mirror of society. It is the criticism of life. It teaches us how to live life. The novels of Charles Dickens are no exception.

The society and people as depicted by Charles Dickens present the true picture of contemporary England. He says, "I want to show how these people act and react in Victorian England and how their action affects the lives of the readers."

Charles Dickens also talks about scientific progress like electricity, telegraph, gas-lighting, stamp-postal system, and medicine of Victorian England in his novels. He said that his characters are lifelike and they are his mouthpieces, especially the central character. Many of his novels are semi-autobiographical and he has written about his own experience in Oliver Twist and Great Expectations. When a novelist gives the first-hand experience of his own life in a piece of literature, its authenticity cannot be questioned. Though he did it with a pinch of imagination it's very close to reality.

All the characters of Great Expectations are life-like which proves Charles Dickens as an ace delineator of characters. His novels are a prism of not only Victorian England but also of the lives of its people. It reflects all-around happenings of the age and how they were interrelated to that period. He says, "Though the advancement in science and technology brought revolution they left many people unemployed too. They inculcated the sense of skepticism in the heart and mind of people." Now people started questioning the existence of God. They began to compare things based on reason and logic. For example, Pip, the protagonist of Great Expectations, accepts the invitation to go to Satis house to play with Estella for his social advancement. When he receives money from his unknown benefactor, he leaves for London. He treats people on a practical basis. Though false seriousness could not be eliminated from his character and he shows all the characteristics of a neo-rich, he is a true representative of a Victorian.

Living in a society where a class enjoys all the luxuries of life whereas the other live hands to mouth, social unrest will be a very common phenomenon. The disparity between the two classes is the root cause of all the evil. It sows the seeds of hatred among the people of the same society. If we don't call it hatred, at least it is very close to it. Wealth is the mother of all evil and it is the sister of hypocrisy and self-righteousness. Charles Dickens has portrayed all these things in his novels so minutely that they seem to be a motion picture. His description of the age is so vivid that we feel as if we have been living in that age and experiencing things on our own. 


\section{Conclusion:}

Great Expectations deals with several themes and it has two plots but the three unities of time, place, and action are so neatly closed that though it was published in a journal in the serialized form it attracted the attention of the reading public of England in a way that soap operas attract the attention of women in the present days. The enthusiastic readers used to wait for the next edition to come to know what will happen in the story next. It was a prism to Victorian social, political, religious, scientific, and economic life. It encompasses almost all the major incidents of Victorian society. It has warm days and cold winters; bursts of sunshine and darkness and love and hatred portrayed artistically. The characters of this novel are so vivid as if they live in our society and their active forms the background of this novel. Thus, it can be analyzed without a doubt that Great Expectations is novel par excellence and Charles Dickens has carved his niche in the history of English novels after the publication of this novel. It is truly said:

"Great Expectations holds a major place in English novels as it is a prism to Victorian England." 